Received: 20 July 2014

Accepted: 10 September 2014

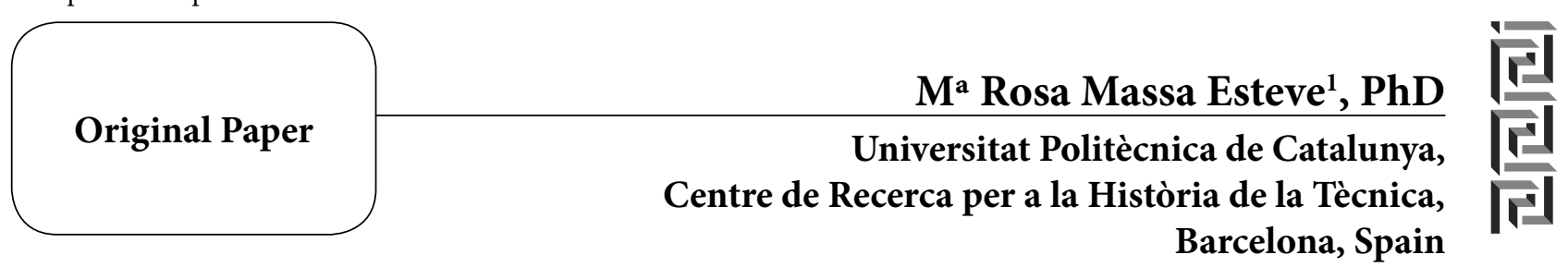

\title{
Historical activities in the mathematics cla- ssroom: Tartaglia's Nova Scientia (1537)
}

\begin{abstract}
The History of Mathematics can be developed both implicitly and explicitly in the classroom. Learning about the history of mathematics can therefore contribute to improving the integral education and training of students. The aim of this paper is to analyze the proposal of an historical activity based on the work Nova Scientia (1537) by Tartaglia for use in the mathematics classroom. This analysis will show the use of a Renaissance mathematical instrument for measuring the height of a mountain in order to motivate the study of trigonometry in the mathematics classroom, as well as to show students the explanatory role of mathematics in regard to the natural world.
\end{abstract}

Key words: History of mathematics, teaching, Niccolò Tartaglia, Nova Scientia, geometry.

\section{Introduction}

The history of mathematics shows how mathematics has frequently been used to solve problems concerning human activity as well as for helping to understand the world that surrounds us. The study of historical processes enables us to see how the different aspects of mathematics have been combined together in a repeated interaction of application and development. Thus, for instance, geometry, which emerged as a means of measure, has evolved alongside the problems of measurement (Stilwell, 2010); trigonometry has developed in order to solve prob-

1 m.rosa.massa@upc.edu

2 This research is included in the project: HAR2013-44643-R. lems of both astronomy and navigation (Zeller, 1944), while algebra, which came more to the fore in problem-solving, especially in mercantile arithmetic during the Renaissance, was later to become an indispensable tool for solving problems in geometry and number theory (Bashmakova \& Smirnova, 2000; Massa Esteve, 2005a). All this knowledge will undoubtedly enrich the mathematical background and training of teachers, some references to which can be found in the historiography (Calinger, 1996; Fauvel \&Maanen, 2000; Demattè, 2006; Massa Esteve et al., 2011; Lawrence, 2012).

In Catalonia, the implementation of the history of mathematics in the classroom has for twenty years inspired some individual initiatives among 
teachers (Romero \& Massa, 2003; Guevara et al., 2008; Roca-Rosell, 2011; Massa-Esteve, 2012). The academic year 2009-2010 saw the inauguration of a new course for training pre-service teachers of mathematics in secondary education. The syllabus of this Master's degree launched at the universities includes a compulsory section on the history of mathematics and its use in the classroom. One of the subjects of this course concerns engineers-artists in the Renaissance, and a proposal of an historical activity on this subject in the mathematics classroom has been presented to pre-service teachers.

The aim of this paper $^{3}$ is to analyze the proposal of the implementation of this historical activity, and also to discuss whether these kinds of activities can show students how mathematics may play an explanatory role in regard to the natural world. Furthermore, the paper considers whether working with instruments and following the procedures recommended to their users in the past offer students today a valuable appreciation of mathematical practices (Heering, 2012).

\section{Usefulness of the history of mathematics in the classroom}

The usefulness of the history of mathematics in the classroom is described through our theoretical and practical approach, with the aim of persuading people about the need for this type of training. Knowledge of the history of mathematics can assist in the enrichment of teaching tasks in two ways: by providing students with a different vision of mathematics, and by improving the learning process (Katz, 2000; Jankvist, 2009; Panagiotou, 2011).

\section{A different vision of mathematics}

Teachers with knowledge of the history of mathematics will have at their command the tools for

3 A first version of this paper was presented in the First European Autumn School of History of Science and Education, 15-16 November 2013 in Barcelona. conveying to students a perception of this discipline as a useful, dynamic, human, interdisciplinary and heuristic science (Massa Esteve, 2003, 2010). Teachers in possession of such knowledge are able to show students a further relevant feature of mathematics that it can be understood as a cultural activity. History shows that societies develop as a result of the scientific activity undertaken by successive generations, and that mathematics is a fundamental part of this process. Mathematics can be presented as an intellectual activity for solving problems in each period. The societal and cultural influences on the historical development of mathematics provide teachers with a view of mathematics as a subject dependent on time and space and thereby add an additional value to the discipline (Katz \& Tzanakis, 2011).

It is also worth pointing out that not only as teachers, but also as mathematicians, the history of mathematics enables us to arrive at a greater comprehension of the foundations and nature of this discipline. The history of mathematics provides the devotees of this science with a deeper approach to an understanding of the mathematical techniques and concepts used every day in the classroom. Knowing history of our discipline helps us explain how and why the different branches of mathematics have taken shape: analysis, algebra and geometry, their different interrelations and their relations with other sciences.

\section{An improvement in the learning process}

The history of mathematics as a didactic resource can provide tools to enable students to understand mathematical concepts better. The history of mathematics can be employed in the mathematics classroom as an implicit and explicit didactic resource (Jahnke et al., 1996).

The history of mathematics as an implicit resource can be employed by teachers in the design phase by choosing contexts, by preparing activities (problems and auxiliary sources) and also by drawing up the teaching syllabus for a concept or an idea. In addition to its importance as an implicit tool for 
improving the learning of mathematics, the history of mathematics can also be used explicitly in the classroom for the teaching of mathematics. Although by no means an exhaustive list, four areas may be mentioned where the history of mathematics can be employed explicitly in Catalonia: 1) for proposing and directing research work at baccalaureate level using historical material; 2) for designing and imparting elective subjects involving the history of mathematics; 3) for holding workshops, anniversary celebrations and conferences, and 4) for implementing significant historical texts in order to improve understanding of mathematical concepts (Massa Esteve, 2005b; Romero et al., 2007, 2009; Massa \& Romero, 2009). This paper is focused on the last point, which is, presenting an historical text involving mathematical instruments employed in the Renaissance.

\section{Historical activities in the mathematics classroom}

Historical texts can be used throughout the different steps in the teaching and learning process: to introduce a mathematical concept; to carry out an exploration of it more deeply; to provide an explanation of the differences between two contexts; to motivate study of a particular type of problem or to clarify a process of reasoning.

In order to use historical texts properly, teachers are required to present historical figures in context, both in terms of their own objectives and the concerns of their period. Situating authors chronologically enables us to enrich the training of students. Thus, students learn different aspects of the science and culture of the period in question in an interdisciplinary way. It is important not to fall into the trap of the amusing anecdote or the biographical detail without any mathematical content. It is also a positive idea to have a map available in the classroom to situate the text both geographically and historically.
Teachers should clarify the relationship between the original source and the mathematical concept under study, so that the analysis of the significant proof should be integrated into the mathematical ideas one wishes to convey. The mathematical reasoning behind the proofs should be analyzed and contextualized within the mathematical syllabus by associating it with the mathematical ideas studied on the course so that students may see clearly that it forms an integral part of a body of knowledge. In addition, addressing the same result from different mathematical perspectives enriches students' knowledge and mathematical understanding (Massa Esteve, 2014).

The aims of the implementation of the historical activity in the mathematics classroom are:

a) To learn about the sources on which knowledge of mathematics in the past is based;

b) To recognize the most significant changes in the discipline of Mathematics; those which have influenced its structure and classification, its methods, its fundamental concepts and its relation to other sciences;

c) To show students the socio-cultural relations of mathematics with politics, religion, philosophy and culture in each period, as well as with other spheres;

d) To encourage students to reflect on the development of mathematical thought and the transformations of natural philosophy.

\section{Case study: Historical activity based on Tartaglia's Nova Scientia (1537)}

The following historical activity deals with the work Nova Scientia (1537) by Niccolò Fontana Tartaglia (1499/1500-1557). In order to implement the activity in the classroom, it is recommendable to begin with a brief presentation of the epoch, the Italian Renaissance, and Tartaglia himself. The aims of the author as well as the features of the work would then 
be analyzed, and finally students are encouraged to construct an instrument for measuring degrees and to follow the reasoning of a significant proof, in order to acquire new mathematical ideas and perspectives. This classroom activity would be implemented in the last cycle of compulsory education (14-16 year olds) with the aim of introducing and motivating the study of trigonometry.

\section{The context: The Italian Renaissance}

The period from the mid- $14^{\text {th }}$ century to the beginning of the $17^{\text {th }}$ century was the age of the Renaissance, so called because it represented the rebirth of interest in the Greece and Rome of Classical antiquity (Rose, 1975; Hall, 1981).

Artists, writers, scientists, and even the more refined craftsmen looked to the past for inspiration and examples on which to model their own work. Latin and Greek were the indispensable keys to style, knowledge, and good taste, assuming a foundational significance in education that they were to retain for centuries. This was the period of the great voyages of discovery which enlarged the horizons of the Western civilization, as did the invention of printing, with its incalculable effects upon human communication and the spread of information. The stream of wealth from the New World helped to develop the already growing economies of Europe. The major influence Renaissance had on technology was in the field of architecture. The abandonment of Gothic forms by the Italian architect Filippo Brunelleschi (1377-1446) and his successors, and the gradual spread of the Neo-Classical Palladian style of building from Italy over the whole of Europe involved changes in building techniques.

Teachers could argue that the inventions of the modern world demonstrated its technological superiority: this was especially the lesson of Jan Stradanus' Nova Reperta (1570), a volume of splendid engravings also produced near the end of the 16 th century. We can use this image of Nova Reperta to show all these advances to students (see Figure 1).

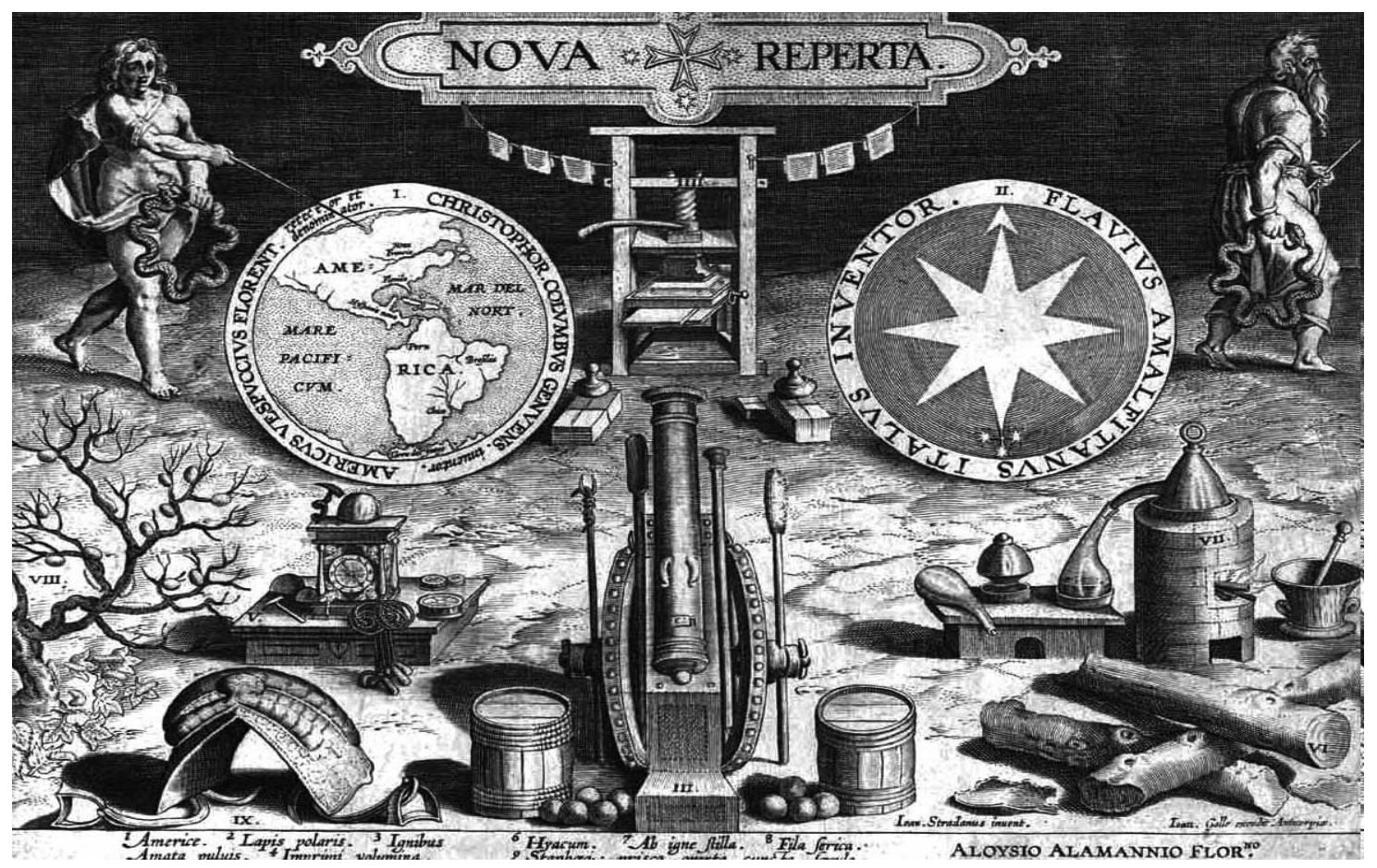

Figure 1. Nova Reperta 
With this image the teacher can discuss with the students how the ancients had not mastered the "super-natural" force of gunpowder, nor discovered how to multiply books and pictures by printing. Neither had they found the direct route to the East, nor the New World to the West; they remained ignorant of the use of the magnetic compass and of other navigational aids which had made the 15th century voyages of discovery possible. The ancients also lacked windmills, iron-shod horses, the art of making spectacles, mechanical clocks and iron-founding.

In terms of the basic inventions and improvements made in the middle Ages, the Renaissance did little more than increase their size and scope. Machines became larger and more intricate and production increased. There were three major innovations during the Renaissance: gunpowder, the compass and printing. However, the Renaissance gave rise to a frame of mind which was increasingly receptive to further technological development.

\section{The historical author: Tartaglia}

Tartaglia, an engineer and scientist of the Renaissance, was taught first in abacus school and then further taught himself mathematics. Tartaglia belonged to that group of engineers and mathematicians who looked upon Archimedes as their rolemodel. Theory, practice, and knowledge and its application were all part of the goal of scientific knowledge of a mathematician. Hence, Tartaglia took a new role and presented a new image of the science of mathematics, which encompassed all these fields of study and action (Bennett \& Johnston, 1996). Some works by Tartaglia are: Nova Scientia $\left(1537,2^{\text {nd }}\right.$ edition 1558), Quesiti et Inventioni Diverse (1546), General Trattato di numeri et misure (1556-1560) and Euclid's Elements (1543).

Tartaglia is deemed as a great mathematician of this period because of his use of geometry, and for his invention and development of a procedure for solving the cubic equation, but which Cardano later published claiming it as his own (Giusti,
2010; Gavagna, 2010). Tartaglia embodied the image of the engineer mathematician that appeared in Italy in the Cinquecento and whose aim was "to solve the problems of his professions and to practice the art of invention".

\section{The historical work: Nova Scientia}

In his work Nova Scientia (1537), Tartaglia introduced a new science: ballistics. In this work he tried to determine the form taken by the trajectory of a cannonball (Valleriani, 2013; Tartaglia, 1998).

In the frontispiece of the work dealing with the theory of ballistic phenomena, Tartaglia presents an image that seems to go back to the Platonic idea, according to which mathematics constitutes the key to the door of science and philosophy. The image depicts two fortresses: One is situated on a top of mountain or hill entitled Philosophy, and flanked by Plato and Aristotle; the other is situated at the bottom, and called the Quadrivium, which of course consists of Music, Arithmetic, Geometry and Astronomy but to which is added a new science: Perspective. Tartaglia is seen at the center as Master of Ceremonies, presenting the principles of science that constituted ballistics. To enter this Sancta Santorum of Knowledge one must pass through a door guarded by Euclid. Euclid's Elements in the Cinquecento period were not only the foundation but the paradigm or manner to attain all wisdom (propaedeutic function) (see Figure 2).

Tartaglia's book is not a treatise on motion in a medieval sense, that is to say, he does not analyze the nature of motion (Tartaglia, 1998). He states that he will address the study of the movement of a projectile ejected from a cannon or by whatever "artificial machine or matter that will be appropriated to throw violently a body equally weighty into the air." (Definition XIII). This current of thinking in, which including the artificial machine into the theoretical investigations, came to the fore in the middle of the XV century (Gessner, 2010). The practice was established by engineers and others trained in the atel- 
iers of craftsmen from the north of Italy and Germany. The machine and its artifices were regarded as a way of conducting research into the world. In fact, the mechanics of the Cinquecento may be regarded as a science of machines. The theoretical analysis of the functioning of machines and their effects is predominant in other subjects in mechanics, but can use geometry because machines such as the balance, the lever and the pulley are simple to analyze by geometric methods.

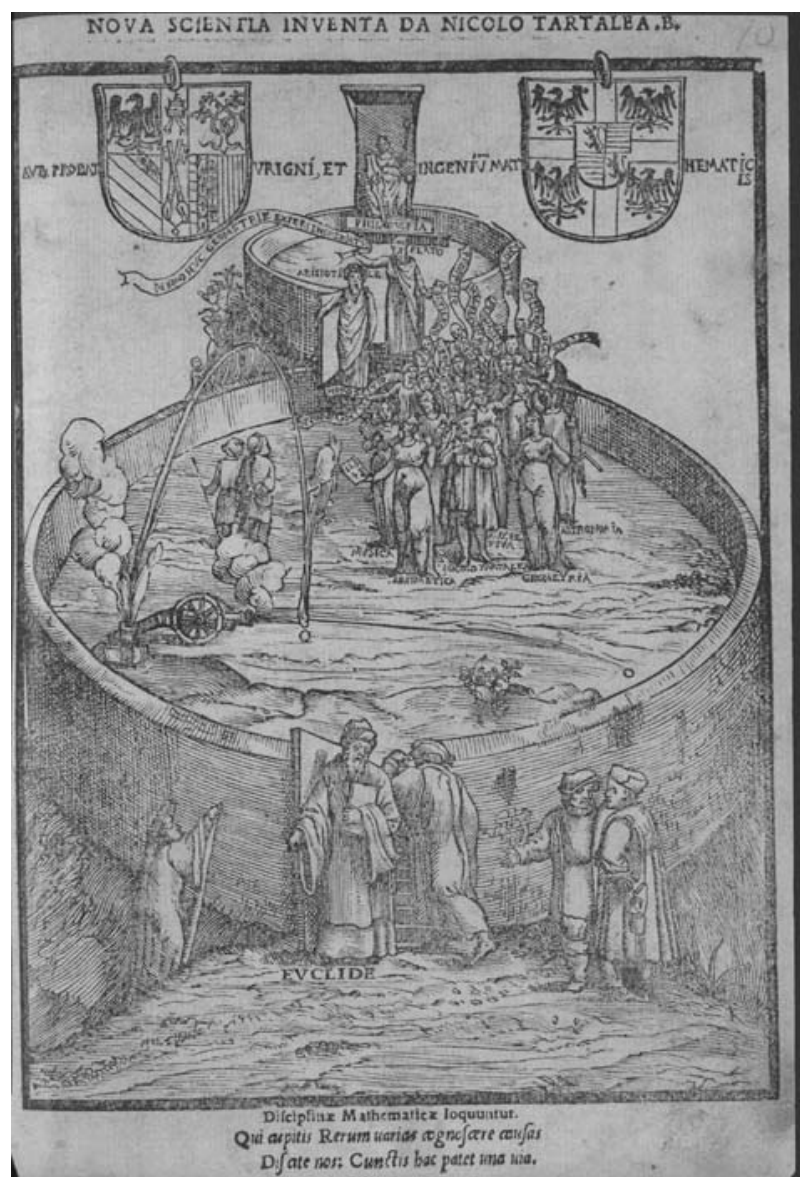

Figure 2. Frontispiece of the Nova Scientia. Tartaglia, 1537.

At that time, the principal problems in the analysis of movement of a cannonball were the questions of what happened when the ball was in the air. These were: By how many degrees should the cannon be inclined to the horizontal so that the ball could hit a target located at a particular distance? At what inclination must a ball be fired so that the expected distance would be the maximum of possible distances?

Tartaglia, who was at the time professor of mathematics at Venice, gave the first answers to these questions. He asserted that the maximum distance of a ball fired from a cannon could be obtained by inclining the cannon $45^{\circ}$ on the horizontal. Furthermore, he provided another answer that was even more surprising; Tartaglia claimed that the trajectory that the ball described through the air consisted of a curve. This claim contradicted the Aristotelian doctrine of movement, according to which the movement that the ball must follow will be a straight line until it reaches its maximum height, after which it will fall vertically to the center of the earth (Henninger-Voss, 2002). Thus, Aristotle's doctrine provided for no curved movement. However, the trajectory of a cannonball according to Tartaglia was composed of three parts; one rectilinear, one curve that follows an arc of circumference, both representing the trajectory's violent motion and, finally, one rectilinear of natural motion (see Figure 3).

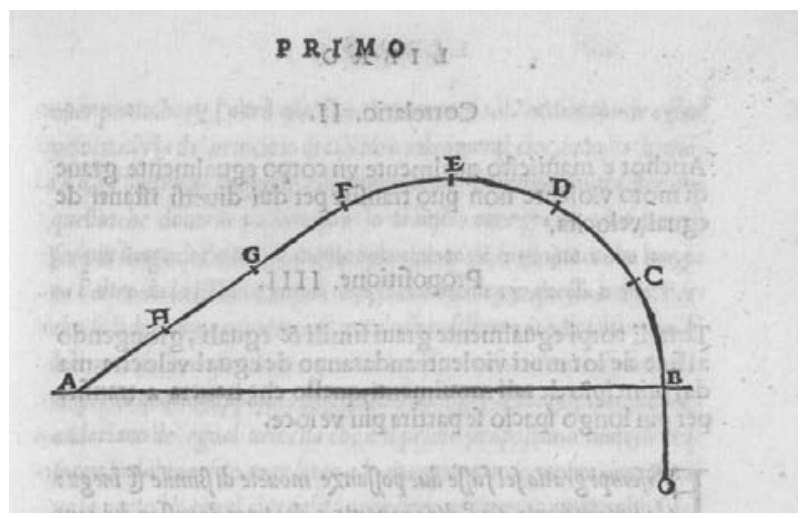

Figure 3. Tartaglia's movement. Tartaglia, 1537.

This work by Tartaglia enjoyed considerable success. By 1583, the text in Italian had reached seven editions and had been translated into many languages. Tartaglia, an expert on the matter, subse- 
quently returned to the problem of movement in his work Quesiti et invention diverse (1546).

\section{The text: the Euclidian way}

Nova Scientia consists of 3 books. The first book contains 14 definitions, 5 suppositions, 4 commune sentences and 6 propositions with some corollaries. Book two contains 14 definitions, 4 suppositions and 9 propositions with some corollaries, and the third book contains 5 definitions and 12 propositions. In looking at Tartaglia's Nova Scientia, teachers in the classroom may comment with the students on the Euclidian way of presenting this new practical science (Ekholm, 2010).

In Proposition I of the first book, Tartaglia states his results on movement, including the following words: "Proposition First. All bodies of equal weight with natural movement, the further they move away from the beginning and approach their end point, the more they gain in speed."

In the fourth supposition of the second book, he again addresses the inclination of the cannon on the horizontal to achieve the maximum distance. Teachers can discuss with students the inclination at which the expected distance would be the maximum (see Figure 4).

In addition, in the Proposition VIII of the second book he proves that the inclination of the cannon must be $45^{\circ}$, basing his reasoning on the proposition VII, where he uses geometry in similar triangles (see Figure 5):

"Proposition VIII. If the same moving power ejects or throws equally heavy bodies, which are similar and equal to each other, violently through the air but in different manners, the one [equally heavy body] that accomplishes its

\footnotetext{
4 The translations are adapted from the English version by Valleriani of Tartaglia's edition of the 1558 (Valleriani, 2013). “Propositione Prima. Ogni corpo egualmente grave nel moto naturale, quanto piu el se andara aluntanando dal suo principio, over appropinquando al suo fine, tanto piu andara veloce." (Tartaglia, 1537).
}

transit at an elevation of 45 degrees above the horizon produces its effect farther away from its beginning and above the plane of the horizon than [if it were] elevated in any other way." ${ }^{5}$

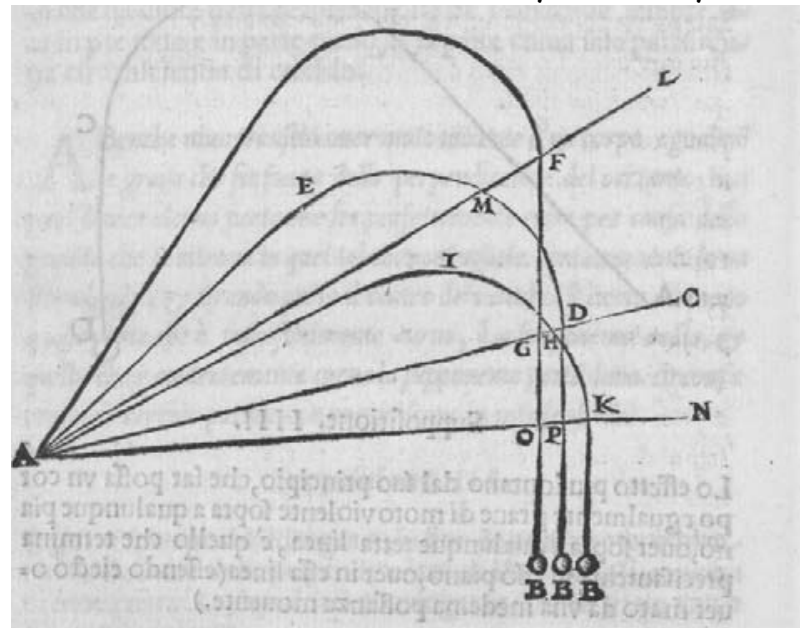

Figure 4. Tartaglia, 1537.

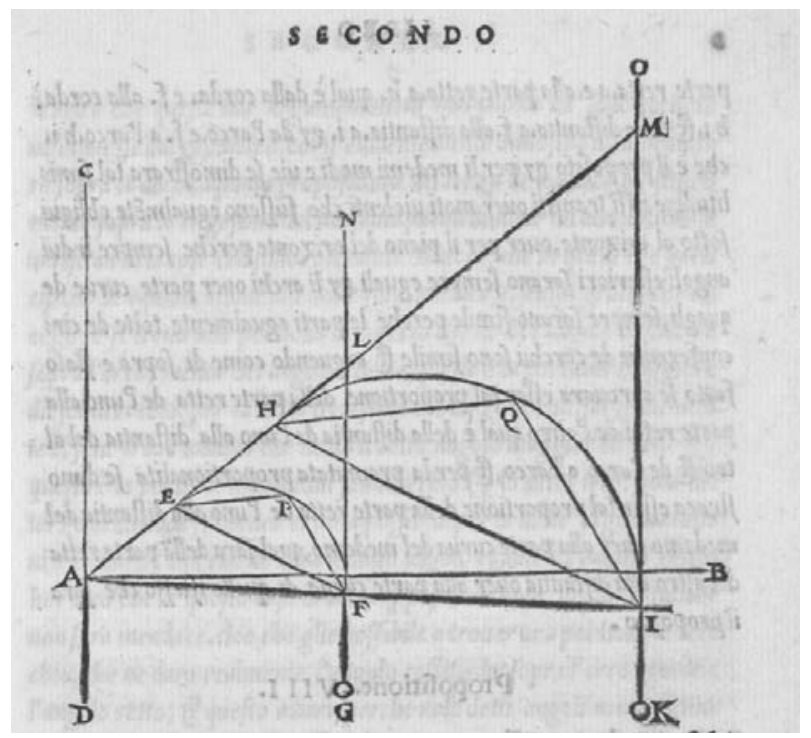

Figure 5. Figure of the Proposition VII. Tartaglia, 1537.

5 „Propositione VIII. Se una medema possanza movente eiettara, over tirara corpi egualmente gravi simili, et eguali in diversi modi violentemente per aere, Quello que fara il suo transito elevato a 45 gradi sopra a l'orizonte fara etià il suo effeto piu lontan dal suo principio sopra il pian de l'orizonte che in qualunque altro modo elevato" (Tartaglia, 1537) 


\section{The mathematical instrument}

Tartaglia constructs two gunner's quadrants, one with a graduate arc to measure the inclination of the cannonball, and the other instrument for solving the problem of measuring the distances and height of an inaccessible object. He offers an explanation of the first instrument at the beginning of the book in the dedicatory letter, as well as examining its construction accurately. He also gives examples with cannon (see Figure 6).

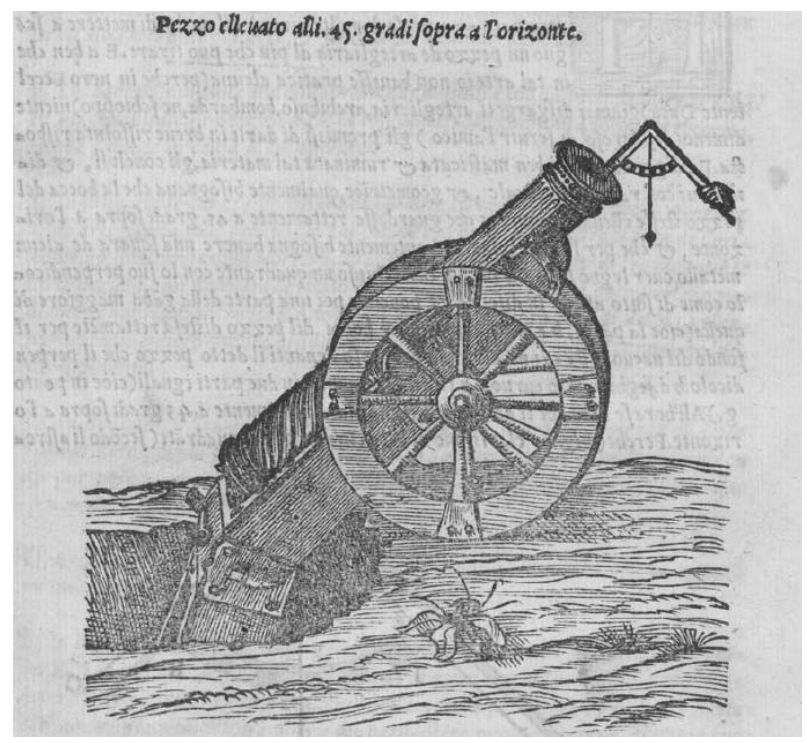

Figure 6. Dedication letter. Tartaglia, 1537.

In the third book, from the Proposition I to the Proposition IV, he provides a description of the material required for constructing the second gunner's quadrant: the rule and the setsquare, and checks its angles in the following propositions. Finally in the Proposition VI of the third book, Tartaglia constructs this gunner's quadrant (see Figure 7).

This gunner's quadrant is used by Tartaglia for measuring the height of inaccessible objects in the propositions of the third book, as shown below.

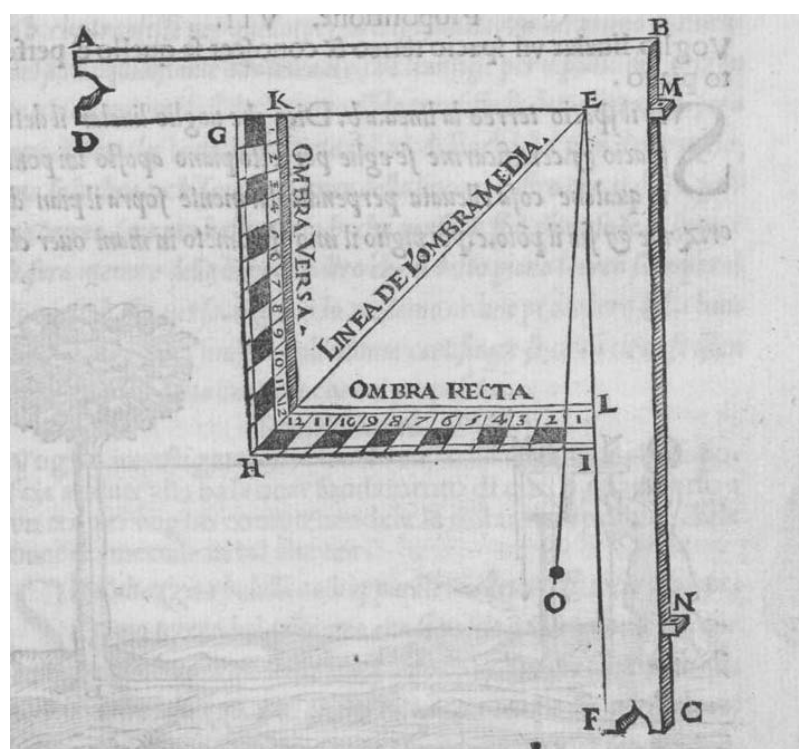

Figure 7. The gunner's quadrant. Tartaglia, 1537.

\section{The significant proof: Proposition VIII of the third book}

The proposition we will look into more detail I find a good example to be employed in the classroom because Tartaglia uses the gunner's quadrant, while at the same time using geometry in similar triangles in the proof to determine the distances and height of an inaccessible object. In the classroom implementation, students could be prompted to reproduce the reasoning of this proof with the geometry of triangles before introducing the trigonometry.

In the Proposition VIII of the third book Tartaglia proves how to obtain the height of a visible, but inaccessible object. He claims:

"I would like to investigate the height of a visible object that one can move to the level of the base, and at the same time I would like to determine the distance through the hypotenuse or diameter of the height." ${ }^{6}$

6 "Propositione VIII. Voglio investigare l'altezza de una cosa apparente che si poscia andaré alla basa, over fondamento di quella, etiam tutto a un tempo voglio comprehendere la distantia ypothumissale, over diametrale di tal altezza”. (Tartaglia, 1537). 
The image of this proposition clarifies the geometric reasoning (see Figure 8):

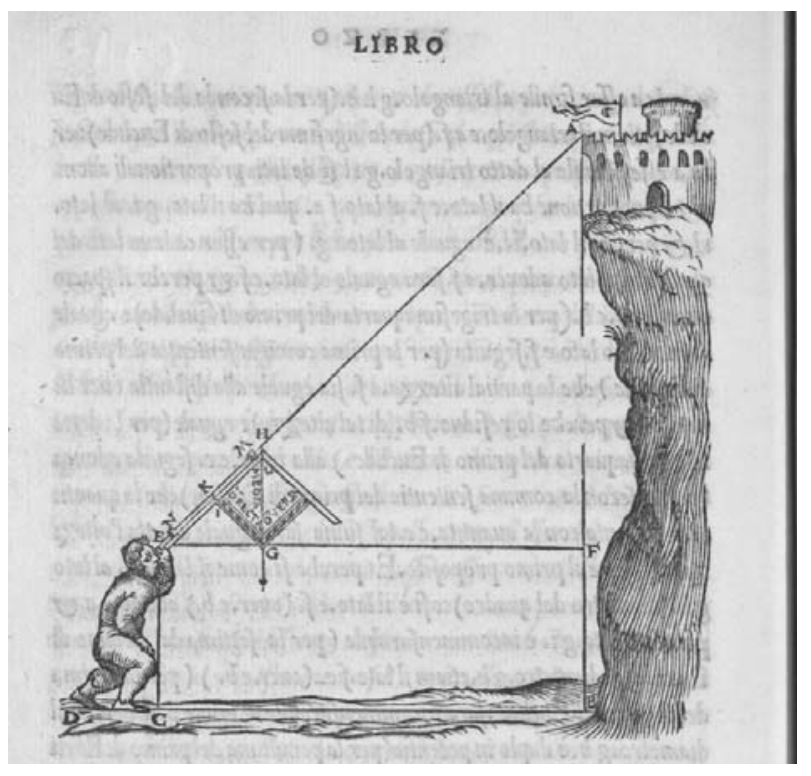

Figure 8. Figure of the Proposition VIII. Tartaglia, 1537.

After providing accurately an explanation of the construction of gunner's quadrant, together with the students the teacher could follow the reasoning of the proof using the similarity of triangles. For example, they can draw a figure with triangles that reproduces the geometric problem (see Figure 9).

Together with the students, the teacher can reproduce the geometrical proof using similar triangles, Pythagoras' theorem and Thales' theorem. ${ }^{7}$ The teacher can also show the use of this figure to solve other problems in the classroom; for instance, the height of a house, or a distance of an object. In fact, these kinds of problems are solved today by trigonometry, and furthermore this historical activ-

7 In this case I am referring to Elements VI. 2: "If a straight line be drawn parallel to one of the sides of a triangle, it will cut the sides of the triangle proportionally; and, if the sides of the triangle be cut proportionally, the line joining the points of section will be parallel to the remaining side of the triangle."(Heath, 1956). ity also justifies the introduction of the teaching of trigonometry.

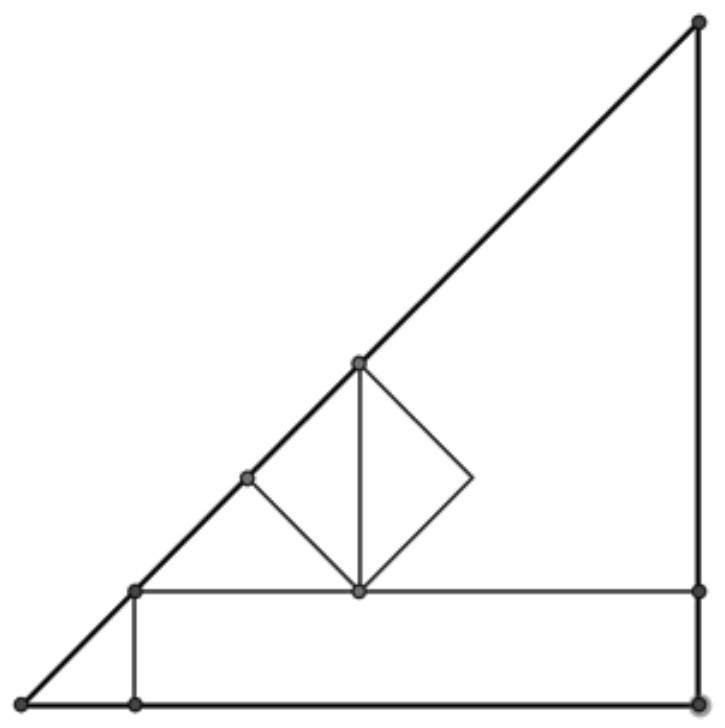

Figure 9. Reproduction of the mathematical problem

\section{Concluding remarks}

In order to transmit to the students the idea that mathematics is a science in a continuous state of evolution, and that it is the result of the joint and ongoing work of many people rather than knowledge amassed by independent contributions arising from flashes of inspiration, it is recommendable to present historical activities in the classroom. This historical activity shows the process from geometry to trigonometry and also how a mathematical instrument can be used in the mathematics classroom, the gunner's quadrant, for instance, or an instrument for measuring degrees, in order to obtain the height of inaccessible objects such as trees or mountains.

As regards to the question posed about whether working with instruments and following the procedures recommended to their users in the past can provide students today with a valuable appreciation of the past practices, it should be taken into account that when working with instruments 
in the classroom, it may not be appropriate to follow exactly the instructions of the users in the past. The function and efficacy of these instructions of the past practices sometimes are not connected to the nowadays world of students. However, the replication of such procedures in the construction of instruments could inspire ideas for constructing similar instruments to reproduce this practice with students today. Students can learn about how mathematical instruments were used in the past to solve real problems.

Actually, in the Renaissance, technological developments in military and artistic spheres, as well as in scientific instruments, were made through the study of mathematics, which became increasingly regarded as a universal tool for solving problems. Thus, the question whether mathematics acquired an explanatory role in regard to the natural world gives rise to further questions about how and why this was so, and leads to discussions on the nature of math- ematics. One may consider that this historical activity clearly shows the explanatory role of mathematics for solving problems of practical geometry in the Renaissance, such as the problem of the inclination of a cannon when one wishes to achieve the maximum distance, as well as the problem of finding the height of inaccessible objects. The mathematical ideas used for the proofs of these propositions can be found in Euclid's Elements: Pythagoras' theorem, Thales' theorem, and in the principles relating to incommensurable lengths. In fact, history of mathematics shows that mathematics is used to address a natural phenomenon, and in this sense it shows the usefulness of mathematics for revealing the natural world. The originality of this historical activity resides in the use of a text, which does not consist entirely of pure mathematics, to give an explanation for the movement of the military projectiles, which could be described as geometrization of real-life problems.

\section{References}

- Bashmakova, I., Smirnova, G. (2000). The Beginnings \& Evolution of Algebra. A. Shenitzer (Trans.), Washington: The Mathematical Association of America.

- Bennett, J., Johnston, S. (1996). The Geometry of War 1500-1750. Oxford: Museum of the History of Science.

- Calinger, R., (ed.) (1996). Vita Mathematica. Historical research and Integration with teaching. Washington: The Mathematical Association of America.

- Demattè, A. (2006). Fare matematica con i documenti storici. Una raccolta per la scuola secondaria di primo e secondo grado. Trento: Editore Provincia Autonoma di Trento - IPRASE del Trentino.

- Ekholm, K. J. (2010). Tartaglia's ragioni : A maestro d'abaco's mixed approach to the bombardier's problem. British Journal for the History of Science, 43 (2), 181-207.

- Fauvel, J. and Maanen, J. V. (ed.) (2000). History in mathematics education: the ICMI study. Dordrecht: Kluwer.

- Gavagna, V. (2010). L'insegnamento dell'aritmetica nel General Trattato di N. Tartaglia. In: Pizzamiglio, P. (ed.), Atti della giornata di studio in memoria di Niccolò Tartaglia, Brescia: Commentari dell'Ateneo di Brescia Suppl.

- Gessner, S. (2010). Savoir manier les instruments: la géométrie dans les écrits italiens d’architecture (15451570). Revue d'histoire des Mathématiques, 16 (1), 1-62.

- Giusti, E. (2010). Linsegnamento dell'algebra nel General Trattato di N. Tartaglia. In: Pizzamiglio, P. (ed.), Atti della giornata di studio in memoria di Niccolò Tartaglia, Brescia: Commentari dell'Ateneo di Brescia Suppl. 
- Guevara, I., Massa, Ma R. and Romero, F. (2008). Enseñar Matemáticas a través de su historia: algunos conceptos trigonométricos. Epsilon, 23 (1 and 2), 97-107.

- Hall, R. R. (1981). La primera tecnología moderna hasta 1600. In: Kranzberg, M. and Pursell, Jr. C. W. (ed.). Historia de la Tecnología. La Técnica en Occidente de la Prehistoria a 1900. Barcelona: Gustavo Gili, S. A.

- Heath, T. L. (ed.) (1956). Euclid. The thirteen Books of the Elements. New York: Dover.

- Heering, P. (2012). Developing and evaluating visual material on historical experiments for physics teachers: Considerations, Experience, and Perspectives. In: Bruneau, O., Heering, P., Laubé, S., Massa-Esteve, M. R. and Vitori, T. (ed.). Innovative Methods for Science Education: History of Science, ICT and Inquiry Based Science Teaching. Berlin: Frank \& Timme GmbH.

- Henninger-Voss, M. J. (2002). How the "New Science" of Cannons Shook up the Aristotelian Cosmos. Journal of the History of Ideas, 63 (3), 371-397.

- Jahnke, H. N., Knoche, N., Otte, M. and Aspray, W. (1996). History of Mathematics and Education: Ideas and Experiences. Göttingen: Vandenhoeck und Ruprecht.

- Jankvist, U. T. (2009). A categorization of the "whys" and "hows" of using history in mathematics education. Educational Stusies in Mathematics, 71 (3), 235-261.

- Katz, V. (ed.) (2000). Using history to Teach Mathematics. An International Perspective. Washington, D. C.: The Mathematical Association of America.

- Katz, V. \& Tzanakis, C. (ed.) (2011). Recent developments on introducing a historical dimension in mathematics education. Washington, D. C.: The Mathematical Association of America.

- Lawrence, S. (2012). Inquiry Based mathematics teaching and the history of mathematics in the English curriculum. In: Bruneau, O., Heering, P., Laubé, S., Massa-Esteve, M. R. and Vitori, T. (ed.). Innovative Methods for Science Education: History of Science, ICT and Inquiry Based Science Teaching. Berlin: Frank \& Timme $\mathrm{GmbH}$.

- Massa Esteve, M. R. (2003). Aportacions de la història de la matemàtica a l'ensenyament de la matemàtica. Biaix, 21, 4-9.

- Massa Esteve, M. R. (2005a). Les equacions de segon grau al llarg de la història. Biaix, 24, 4-15.

- Massa Esteve, M. R. (2005b). L'ensenyament de la trigonometria. Aristarc de Samos (310-230 aC.). In: Grapi, P. and Massa, M. R. (eds.). Actes de la I Jornada sobre la història de la ciència i l'ensenyament. Barcelona: Societat Catalana d'Història de la Ciència i de la Tècnica.

- Massa Esteve, Ma R and Romero, F. (2009). El triangle aritmètic de Blaise Pascal (1623-1662). Biaix, 29, 6-17.

- Massa Esteve, Ma R. (2010). Understanding Mathematics through its History. In: Hunger, H. (ed.). Proceedings of the 3rd International Conference of the European society for the History of Science. Vienna: European Society for the History of Science.

- Massa-Esteve, M. R., Guevara, I, Romero, F. and Puig-Pla, C. (2011). Understanding Mathematics using original sources. Criteria and Conditions. In: Barbin, E., Kronfellner and M., Tzanakis, C. (eds). History and Epistemology in Mathematics Education. Proceedings of the Sixth European Summer University. Vienna: Verlag Holzhausem GmbH. 
- Massa-Esteve, M. R. (2012). The Role of the History of Mathematics in Teacher Training using ICT. In: Bruneau, O., Heering, P. , Laubé, S., Massa-Esteve, M. R. and Vitori, T. (ed.). Innovative Methods for Science Education: History of Science, ICT and Inquiry Based Science Teaching. Berlin: Frank \& Timme GmbH.

- Massa Esteve, M. R. (2014). Álgebra y geometría en el aula: la construcción geométrica de la solución de la ecuación de segundo grado. In: Blanco, M. (coord.). Enseñanza e Historia de las Ciencias y de las Técnicas: Orientación, Metodologías y Perspectivas. Barcelona: SEHCYT.

- Panagiotou, E. N. (2011). Using History to Teach Mathematics: The Case of Logarithms. Science \& Education, 20, 1-35.

- Roca-Rosell, A. (2011). Integration of Science education and History of Science: The Catalan Experience. In: Kokkotas, P. V., Malamitsa, K. S. and Rizaki, A. A. (ed.). Adapting Historical Knowledge Production to the Classroom. Rotterdam: Sense Publishers.

- Romero, F. and Massa, M. R. (2003). El teorema de Ptolemeu. Biaix, 21, 31-36.

- Romero, F., Guevara, I. and Massa, M. R. (2007). Els Elements d'Euclides. Idees trigonomètriques a l'aula. In: Grapi, P. and Massa, Ma R. (ed.). Actes de la II Jornada sobre Història de la Ciència i Ensenyament "Antoni Quintana Marí». Barcelona: Societat Catalana d'Història de la Ciència i de la Tècnica.

- Romero, F., Puig-Pla, C., Guevara, I. and Massa, M. R. (2009). La trigonometria en els inicis de la matemàtica xinesa. Algunes idees per a treballar a l'aula. Actes d'Història de la Ciència i de la Tècnica, 2 (1), 419-426.

- Rose, P. L. (1975). The Italian Renaissance of Mathematics: Studies on Humanists and Mathematicians from Petrarch to Galileo. Geneva: Libraire Droz.

- Stilwell, J. (2010) (First ed. 1989). Mathematics and Its History. Berlin: Springer.

- Tartaglia, N. (1537). Nova Scientia, Venice.

- Tartaglia, N. (1998). La Nueva Ciencia. Introduction and translation with notes (R. Martínez and C. Guevara), Col-lection MATHEMA, México D. F.: Facultad de Ciencias, UNAM.

- Valleriani, M. (2013). Metallurgy, Ballistics and Epistemic Instruments. The Nova Scientia of Nicolò Tartaglia. A New Edition. Max Planck Research Library for the History and Development of Knowledge. Sources 6. Berlin: Edition Open Acces. Retrieved November 6, 2014. from www: http://www.edition-open-sources.org/

- Zeller, S. M. C. (1944). The Development of trigonometry from Regiomontanus to Pitiscus. Michigan: University of Michigan, Ann Astor. 


\section{др Марија Роза Маса Естеве}

Политехнички универзитет Каталоније, Истраживачки центар за историју технологије, Барселона, Шпанија

\section{Историјске активности на часовима математике: Тартаљина Nova Scientia (1537)}

Историјски садржаји математике могу да се развијају и имплицитно и експлицитно на часовима. Учење о историји математике може да допринесе побољшању интегралног образовања и оспособљавања ученика. Историју математике, као имплицитни извор, наставници могу да користе да би осмислили фазу часа користећи различите контексте, припремајући наставне активности (проблемске ситуације и помоћне изворе за сазнавање) и креирајући наставни силабус у функцији формирања појмова или идеја. Осим као имплицитном средству за побољшање учења математике, историја математике може да се користи експлицитно у разреду ради поучавања математике. Имплементација важних историјских текстова може да обезбеди средства која ће ученицима омогућити да боље разумеју математички појам. Циљеви имплементације историјске активности на часовима математике су: а) учење о изворима на којима се заснива знање математике у прошлости; б) препознавање најзначајнијих промена у математичким дисциплинама - оне које су утицале на структуру и класификацију, на њене методе, основне појмове и везу са другим наукама; в) указивање ученицима на социокултурну везу математике и политике, религије, филозофије и културе, у сваком периоду, као и везе са осталим сферама, и коначно, што је најважније, подстицање ученика да се изразе увези са математичком мишљу и трансформацијом природне филозофије. Циљ овог рада је анализа студије случаја предлога историјске активности, базиране на раду „Nova Scientia“ (1537) Никола Фонтане Тартаље (Niccolò Fontana Tartaglia (1499/1500-1557)), за коришћење на часовима математике. Ова анализа ће показати употребу ренесансног математичког инструмента за мерење висине планине да би се мотивисало проучавање тригонометрије на часовима математике, као и показивање улоге математике у објашњавању природног света. Штавише, у раду разматрамо да ли рад на инструментима и мерења помоћу њих, препоручиваних корисницима у прошлости, омогућавају ученицима у садашњости адекватно вредновање мерењем инструментима из прошлости.

Клучне речи: историја математике, поучавање, Николо Тартаља, „Nova Scientia“, геометрија. 